\title{
SIMULATION OF TEMPERATURE, VISCOSITY AND FLOW STRESS OF T-JOINT DURING FRICTION STIR WELDING ON ALUMINUMALLOY
}

\author{
AA6082 \\ Sagar A.Nimkar ${ }^{1}$, Keval A.Rathod ${ }^{2}$, Jay M.Shah ${ }^{3}$, Kushal K.Bariya ${ }^{4}$ \\ ${ }^{I}$ UG Student in Mechanical Engineering, Vadodara Institute of Engineering, Vadodara, Gujarat, India \\ ${ }^{2} U G$ Student in Mechanical Engineering, Vadodara Institute of Engineering, Vadodara, Gujarat, India \\ ${ }^{3} U G$ Student in Mechanical Engineering, Vadodara Institute of Engineering, Vadodara, Gujarat, India \\ ${ }^{4} U G$ Student in Mechanical Engineering, Vadodara Institute of Engineering, Vadodara, Gujarat, India
}

\begin{abstract}
The present paper give study about the Friction Stir Welding on T-Joint using tool as Cold work die steel(H-13) and work piece material as AA6082.The speed of tool (pin and shoulder type), has been taken as $1600 \mathrm{rpm}, 1700 \mathrm{rpm} \& 1800 \mathrm{rpm}$ and its translational speed as $4.23 \mathrm{~mm} / \mathrm{s}$. The temperature of the work piece plates is to be $20^{\circ} \mathrm{C}$. The work piece consists of two uniform material plate of aluminum alloy AA6082 for the experiment purpose. This study will show the temperature distribution, the stress distribution and the viscosity flow in the work piece plates at the give parameters at specified boundary condition. The experimental graphs will give the clear idea about the results of the experiment and thus will give the comparison of parameters at different speed of the tool.
\end{abstract}

Keywords: T-Joint, Friction Stir Welding, Temperature, Flow Stress, Viscosity, AA6082. $* * *$

\section{INTRODUCTION}

The friction Stir Welding (FSW) is one of the most popular and recently used techniques for the joining of the two similar or dissimilar metal and their alloys. It is a solid state and plastic welding process in which the coalescence is obtained by heat generated due to the mechanically induced pressure and vibration between the work piece and the tool. In this technique the work pieces are hold together firmly under pressure in a clamp and a high speed rotated tool is allowed to slide over the meshing surface. The high friction between the meshing and the tool create the coalescence by the heat produce by which the metal comes to its plastic stage. Thus after the cooling of this work piece the required joint is obtained.

The Cold work steel(H-13) tool is high-speed tool which falls under the Group M steels and have low initial cost compared to other elements of the same group. Its density is around $7870 \mathrm{~kg} / \mathrm{m}^{3}$ (metric) and melting point is $1427^{\circ} \mathrm{c}$ (metric) along with the hardness as 28.0-30.0

Rockwell C, Poisson's Ratio 0.27-0.30 and Elastic Modulus as 190-210 GPa (metric).

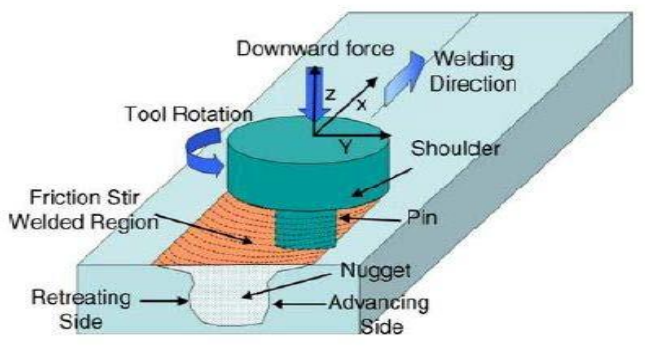

Figure 1: Schematic Diagram of FSW (Reference: 1)

The aluminum alloy series from 7000 onwards are mostly non-weld able by the conventional techniques due to the poor solidified microstructure, porosity in the fusion zone and also due to the remarkable loss in the mechanical properties during the fusion process while compared to their base metals.

\section{LITERATURE SURVEY}

Some of the given below are the experimental and researches done on the FSW process on different joints i.e. butt or lap and by using different tool pin geometry.

Jaimin B Patel, K.D Bhatt and Maulik Shah presented a new tool pin geometry of a hexagon type for the experimental purpose on AA6061 alloy and presenting its peak temperature and flow process. . They after the experiment concluded that comparatively low peak temperature of $300^{\circ} \mathrm{C}$ provides minimum flow stress of 151.8MPa for Hexagonal pin profile as compared to cylindrical pin profile. The peak temperature of $\sim 545^{\circ} \mathrm{C}$ 
is achieved for cylindrical pin profile with moderately high flow stresses ( 210MPa).

K.D Bhatt and Bindu Pillai present paper is to simulate peak temperature and distribution of flow stresses produced during the FSW of AA7050-T7451 Aluminum alloy. They came to conclusion that at constant tool rotational speed (RS) and tool with the same geometry.

Also the variation in tool traverse speed has prominent effects on temperature history \& flow stresses developed during FSW of AA7050-T7451 Aluminum alloy. The flow stresses at lower peak temperature of 3400C are as high as $720 \mathrm{MPa}$ but are as low as $680 \mathrm{MPa}$ at higher peak temperature of $3600 \mathrm{C}$. Also with the increase in welding speed, the peak temperature also increase if the rotational speed of the tool is kept constant.

Rhodes et al. investigated on the microstructure evolution in AA7075-T651 during FSW process. He concluded that maximum process temperatures are between about $400^{\circ} \mathrm{c}$ to $4800^{\circ} \mathrm{c}$ in the AA7075-T651.

\section{EXPERIMENTAL WORK AND RESULTS}

The properties of the work piece plates and the tool are given in the following tables.

Table 1: Properties of AA6082

\begin{tabular}{|c|c|}
\hline Density & $2660 \mathrm{Kg} / \mathrm{m}^{3}$ \\
\hline Specific Heat & $896 \mathrm{~J} / \mathrm{Kg}-\mathrm{K}$ \\
\hline Conductivity & $198 \mathrm{~W} / \mathrm{m}-\mathrm{K}$ \\
\hline $\begin{array}{c}\text { Coefficient of Thermal } \\
\text { Expansion }\end{array}$ & $1 \mathrm{e}-0051 / \mathrm{K}$ \\
\hline Young's Modulus & $4.00 \mathrm{E}+10 \mathrm{~Pa}$ \\
\hline Poisson's Ratio & 3.50 \\
\hline
\end{tabular}

Table 2: Properties of Cold work

\begin{tabular}{|c|c|}
\hline \multicolumn{2}{|c|}{ steel(H-13) } \\
\hline Density & $7870 \mathrm{~kg} / \mathrm{m}^{3}$ \\
\hline Specific Heat & $460 \mathrm{~J} / \mathrm{Kg}-\mathrm{K}$ \\
\hline Conductivity & $24.3 \mathrm{~W} / \mathrm{m}-\mathrm{K}$ \\
\hline Young's Modulus & $2.1 \mathrm{E}+11 \mathrm{~Pa}$ \\
\hline Poisson's Ratio & 0 \\
\hline
\end{tabular}

The Boundary Condition Parameters for the T-Joint are stated in the following table.

Table 3: Boundary Conditions

\begin{tabular}{|c|c|}
\hline Temperature of Plates & $20^{\circ} \mathrm{c}$ \\
\hline Translational speed & $4.23 \mathrm{~mm} / \mathrm{s}$ \\
\hline Rotational Speed & $1600 / 1700 / 1800 \mathrm{rpm}$ \\
\hline Slip Coefficient & $1.0 \mathrm{e}+09$ \\
\hline
\end{tabular}

The following figures show the graphical representation of the Flow Stress, Temperature Distribution, and the viscosity flow in the plates at a Tjoint when FSW is applied.

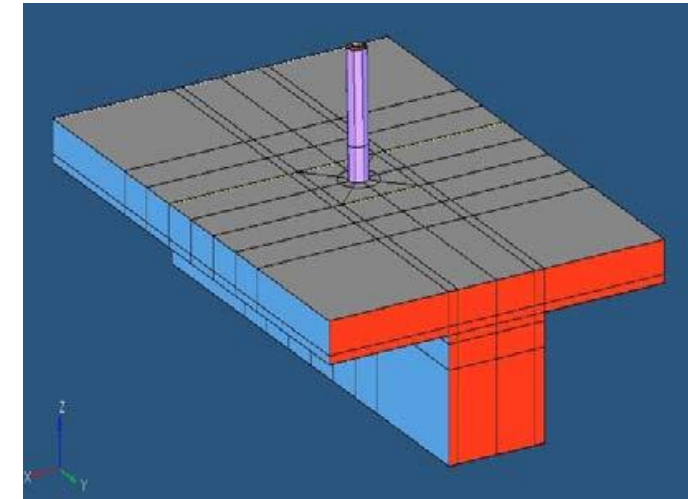

Figure 2: Model ISO View

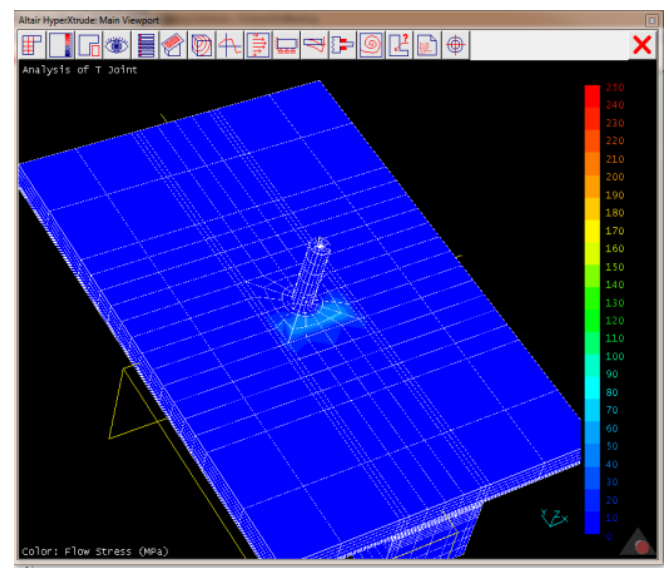

Figure 3: Flow Stress at $1600 \mathrm{rpm}$

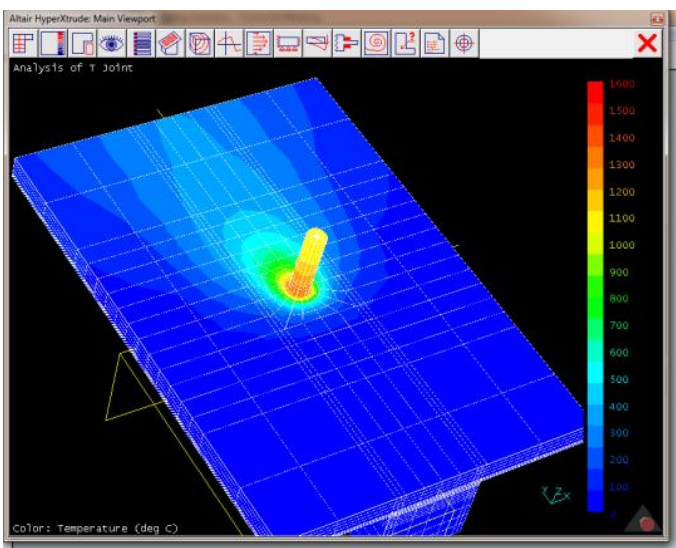

Figure 4: Temperature Distribution at 1600rpm

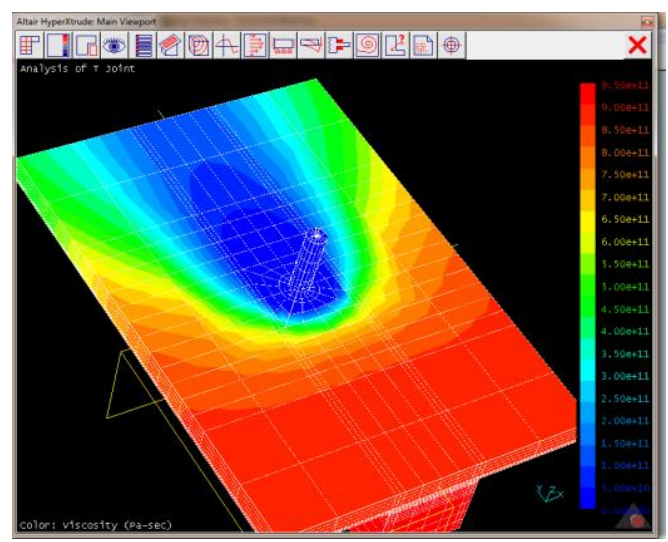

Figure 5: Viscosity result at $1600 \mathrm{rpm}$ 


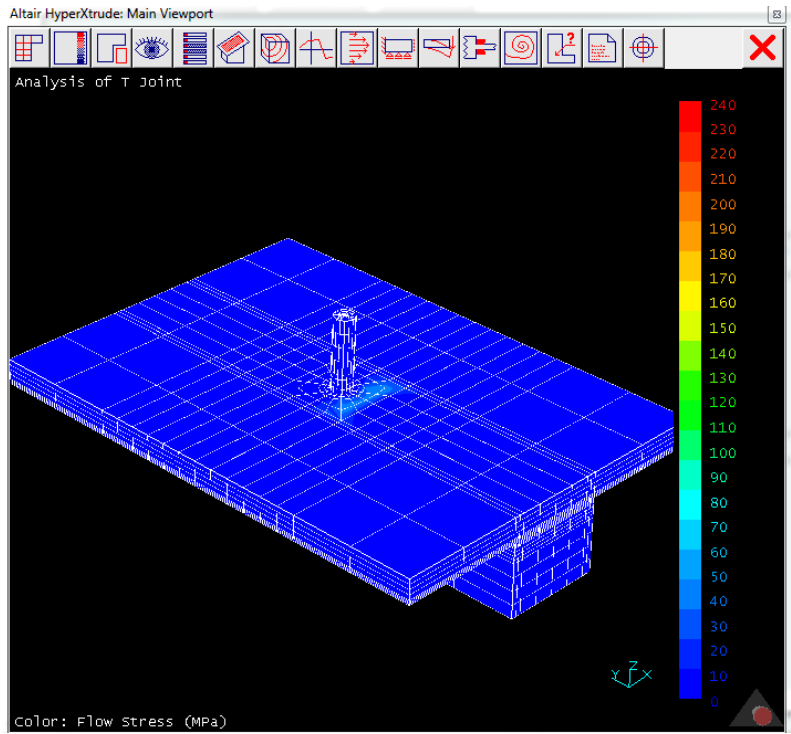

Figure 6: Flow Stress at $1700 \mathrm{rpm}$

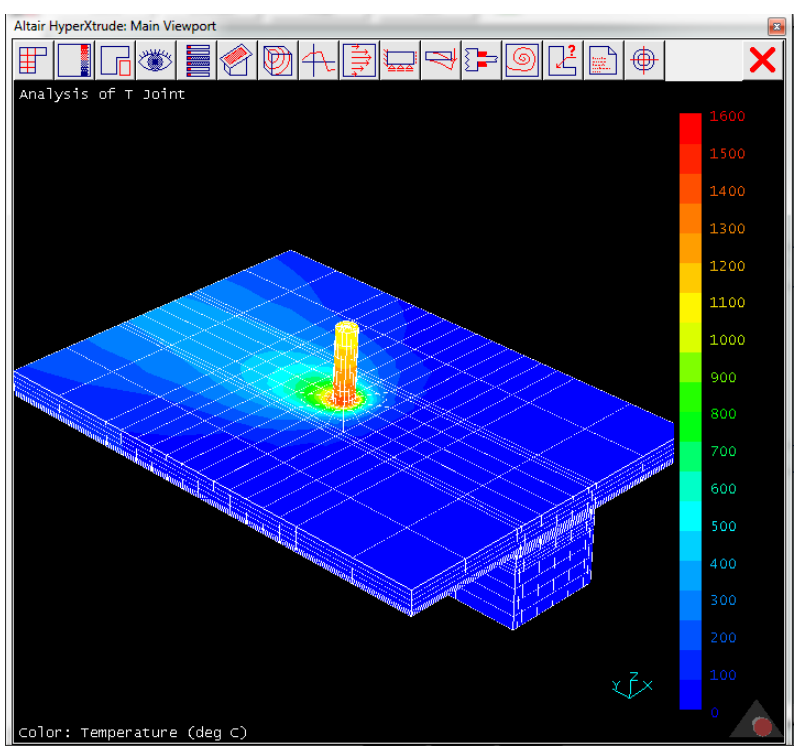

Figure 7: Temperature Distribution at $1700 \mathrm{rpm}$

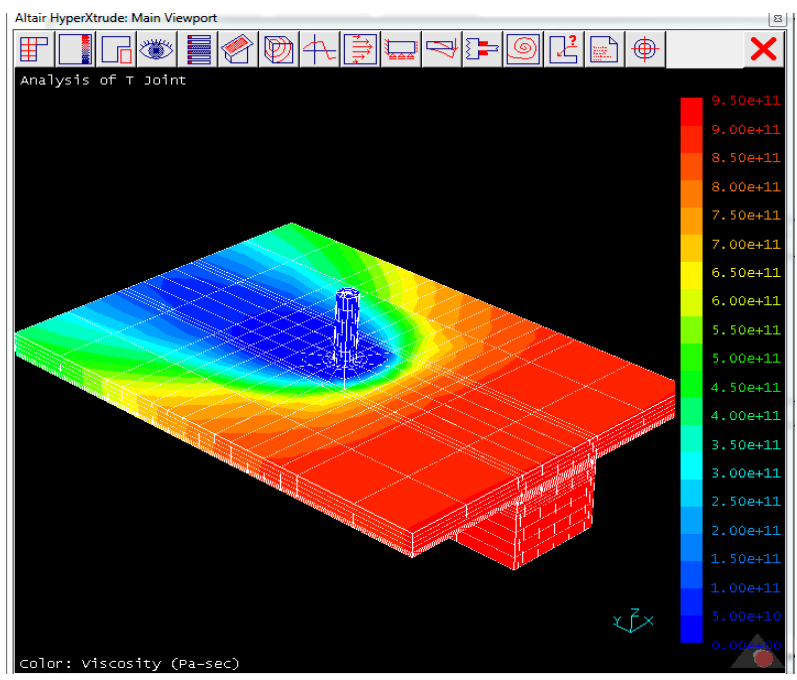

Figure 8: Viscosity result at $1700 \mathrm{rpm}$

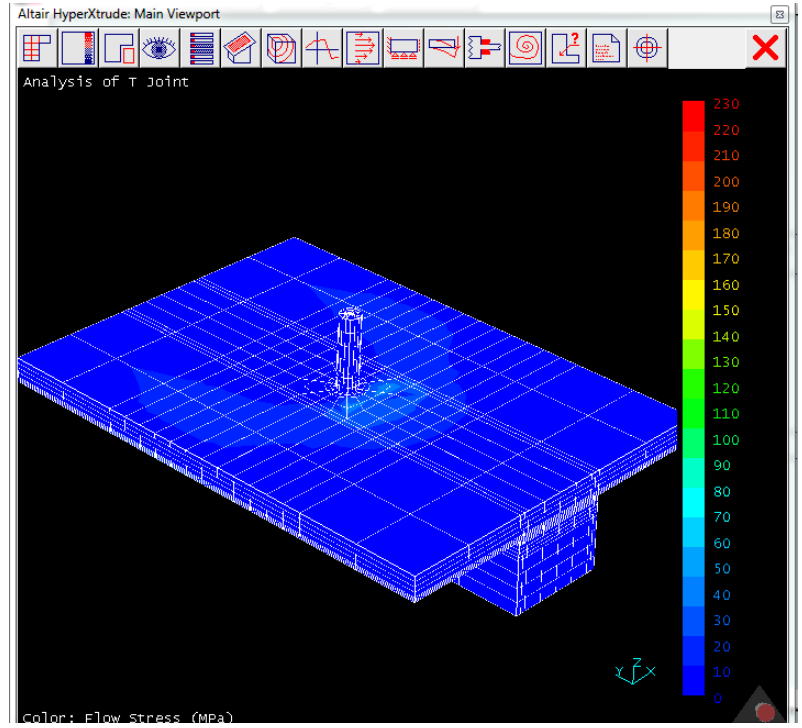

Figure 7: Flow stress result at $1800 \mathrm{rpm}$

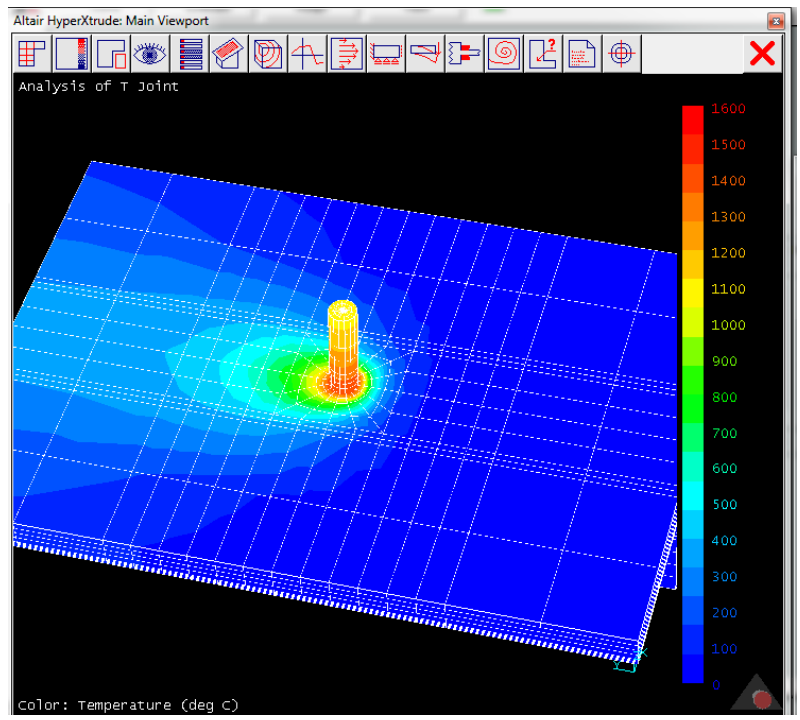

Figure 10: Temperature Distribution at $1800 \mathrm{rpm}$

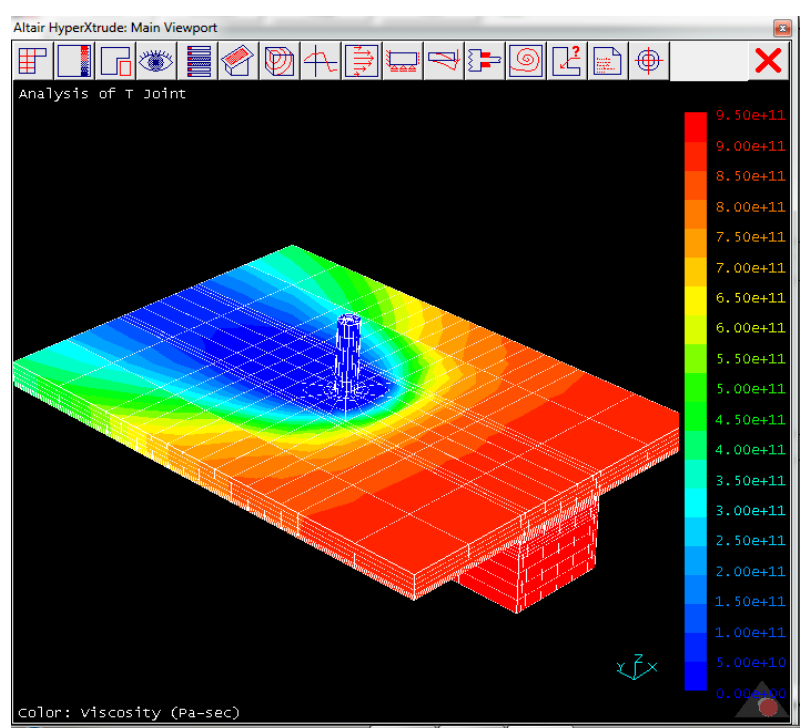

Figure 11: Viscosity result at $1800 \mathrm{rpm}$ 


\section{RESULT TABLE}

\begin{tabular}{|c|c|c|c|}
\hline $\begin{array}{c}\text { Speed } \\
(\mathrm{rpm})\end{array}$ & $\begin{array}{c}\text { Flow Stress } \\
(\mathrm{MPa})\end{array}$ & $\begin{array}{c}\text { Temp. } \\
\text { Distribution } \\
\left({ }^{\circ} \mathrm{C}\right)\end{array}$ & $\begin{array}{c}\text { Viscosity } \\
(\mathrm{Pa}-\mathrm{sec})\end{array}$ \\
\hline 1600 & 250 & 160 & $9.50 \mathrm{e}+11$ \\
\hline 1700 & 240 & 160 & $9.50 \mathrm{e}+11$ \\
\hline 1800 & 230 & 160 & $9.50 \mathrm{e}+11$ \\
\hline
\end{tabular}

\section{CONCLUSIONS}

From the results of the simulation and analysis of the experiment we arrive at the following conclusions.

1. At $1600 \mathrm{rpm}$ of the tool rotation the maximum flow stress is $250 \mathrm{MPa}$, the maximum temperature distribution over plates is $1600^{\circ} \mathrm{c}$ and the maximum viscosity is $9.50 \mathrm{e}+11 \mathrm{~Pa}$-sec.

2. At $1700 \mathrm{rpm}$ of the tool rotation the maximum flow stress is $240 \mathrm{MPa}$, the maximum temperature distribution over plates is $1600^{\circ} \mathrm{c}$ and the maximum viscosity is $9.50 \mathrm{e}+11 \mathrm{~Pa}$-sec

3. At $1800 \mathrm{rpm}$ of the tool rotation the maximum flow stress is $230 \mathrm{MPa}$, the maximum temperature distribution over plates is $1600^{\circ} \mathrm{c}$ and the maximum viscosity is $9.50 \mathrm{e}+11 \mathrm{~Pa}-\mathrm{sec}$

4. Thus as tool rpm goes on increasing the flow stress decrease, the temperature distribution remains the same and the viscosity remains constant.

\section{REFERENCES}

[1] K.D.Bhatt, Bindu Pillai, "Simulation of Peak Temperature \& Flow Stresses during Friction Stir Welding of AA7050- T7451 Aluminum Alloy Using Hyper works", International Journal of Emerging Technology and Advanced Engineering, ISSN 2250 2459, Volume 2, Issue 5,(May 2012).

[2] Jaimin B. Patel, K. D. Bhatt, Maulik Shah, "Replacement of Tool-pin Profile and Simulation of Peak Temperature \& Flow Stress during FSW of AA6061 Alloy", using hyper works software, Vol. 1 Issue 5, July 2014.

[3] C.G. Rhodes, J.G. Flintoff, R.A. Spurling, W.H. Bingel, Metall. Mater. Trans. A 29 (1998) 1955.

[4] Fabrication Technology by S. V. Gosai, Retd. Trg. Placement Officer, Govt College, Porbandar.

[5] Effect of initial base metal temper on mechanical properties in AA7050 friction stir welds, J Yan \& AP Reynolds, Science \& technology of welding \& joining, 2009.

[6] Corrosion behavior of friction stir welded AA7050T7651, JB Lumsden, corrosion journal, 2003.

[7] Effect of thermal boundary condition in friction stir welded AA7050-T7 sheets, P Upadhyay, Material science \& engineering, 2010.

\section{BIOGRAPHIES}

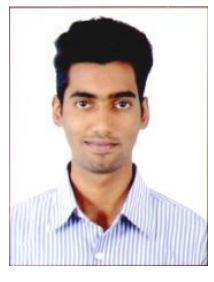

Sagar A. Nimkar has currently studying as a third year student in Vadodara Institute Of Engineering (GTU). His research interests are Industrial Engineering, Analysis \& Simulation of FSW joints, Manufacturing Processes, AutoCAD and Business Management and so on.

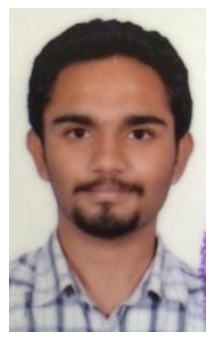

Keval A. Rathod has currently studying as a third year student in Vadodara Institute Of Engineering College (GTU). His research interests are Manufacturing processes, Robotics, Industrial engineering, Analysis \& Simulation of FSW joints, Creo and Hyperworks so on.

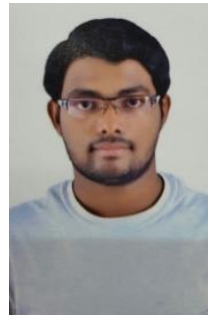

Jay M. Shah has currently studying as a third year student in Vadodara Institute Of Engineering College (GTU). His research interests are Automobile Engineering, Manufacturing \& Production, Theory Of Machines, Robotics, Analysis \& Simulation of FSW joints on different Alloys, Hyperwork and so on.

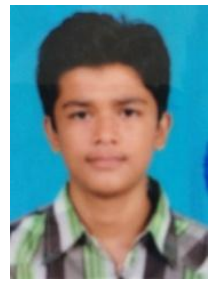

Kushal K. Bariya has currently studying as a third year student in Vadodara Institute of Engineering College (GTU). His research interests are Analysis \& Simulation of FSW joints, Manufacturing processes, Automobile Engineering and so on. 